\title{
The Making of a Classic Ethnography: Notes on Alice Goffman's On the Run
}

\author{
John Van Maanen \\ Massachusetts Institute of Technology \\ Cambridge, MA 02142 \\ Tel: (617) 253-3610 \\ e-mail: jvm@mit.edu \\ Mark de Rond \\ University of Cambridge \\ Cambridge CB2 1AG, United Kingdom \\ Tel +44(0)1223764135 \\ e-mail: mejd3@cam.ac.uk
}

Goffman, A., 2014. On the Run: Fugitive Life in an American City. NY: Picador.

\begin{abstract}
We wish to thank Jean Bartunek for her uncompromising efforts in helping to bring this paper to fruition. We also thank Dvora Yanow, Annette Lareau, Tim Black, Isaac Holeman, and the panelists of the 'Author Meets Critics' session at the 2014 American Sociological Association Annual Meeting (San Francisco) for their input.
\end{abstract}


It is rare for a scholarly ethnography written by a young untenured professor to generate the sort of buzz ordinarily reserved for the progeny of Toni Morrison, Salman Rushdie, Philip Roth or Margaret Atwood. Yet Alice Goffman's (2014) On the Run: Fugitive Life in an American City has more or less done precisely that, and drawn more positive attention than almost any social science work in years. The book - her first - has been widely praised for its gut-wrenching, incisive representation of the social life of young African-American men hounded by the police in a poor, inner-city Philadelphia neighborhood - a world of which most of us have limited, if any, knowledge. Reviewers hailed it as "a remarkable feat of reporting" (Alex Kotlowitz in New York Times Sunday Book Review), "extraordinary" (Malcolm Gladwell in New Yorker), destined to become "an ethnographic classic" (Christopher Jencks in the New York Review of Books).

But, as might be expected given the acclaim and attention generated since its publication, the book has also come in for some sober criticism, the majority of which has come from legal scholars and journalists. Indeed, any book that raises important questions about research ethics coupled with the near-impossibility of specifying consensual rules surrounding ethnography is bound to stir controversy. Who, for example, has the right to study, analyze, and describe the lives of marginalized segments of society? How is the Herculean task of telling what it is like to be someone else best accomplished? What is the right mix of involvement and detachment, reportage and interpretation in the setting? How far does one go to protect the identities of those one is close to in the field? How can Alice's claims to truth be assessed in light of the anonymity cloak that covers her representation? 
The questions raised are many and they are provoking. There are no easy answers since ethnography is always a messy affair. What to one reader is a virtue of the work is, to another, a vice. In this footnote to On the Run, we chase down questions of veracity, of betrayal, of exploitation, and of participation that surround the work. These are matters of particular relevance to a number of organizational and occupational researchers who regard their fieldwork and textual practices as well within ethnographic traditions. Few studies offer a better, closer, or more intense depiction and forthright confrontation of the moral dilemmas that are more or less baked into immersion ethnography. This is the sort of work in which the fieldworker subjects herself - her own body, her own personality, her own social situation - to the life contingencies of those studied and seeing not just what is happening in the research site but feeling it, bodily and emotionally. Since various occupational and organizational ethnographies are making something of splash of late in the management research literatures, a close look at this high profile ethnography is warranted - especially in light of the inordinate commentary, both praiseworthy and blameworthy, it has generated. ${ }^{1}$

\footnotetext{
${ }^{1}$ We have in mind here a number of book-length ethnographies published over the last 10 or so years that have received considerable attention from various scholarly communities in the management and organization research worlds. A small sample includes: Anteby $(2008,2013)$, Barley and Kunda ((2006), Ho (2009), Kellogg (2011), Lane (2011), Nadeem (2011), Sharone (2013) and Turco (2016). Considerable ethnographic work is found in the area journals as well, albeit edited to reflect the presentational penchants ("asphalting") of particular journals including this one predilections that cover such matters as acceptable length, format, framing, research design, presentation of findings, method and analysis discussion, theory development, and so on.
} 
We begin by considering the literary merits - and they are considerable - of $\mathrm{On}$ the Run. Next, we examine the contested ground that it covers representationally and consider some of the empirical or scientific strengths of the book. The following section takes up certain (disputable) allegations reviewers have raised in appraising the work and offers our assessment of these claims. Finally, we conclude by drawing out some general characteristics regarding what we consider to be high quality or "classic" ethnography and consider Alice Goffman's book in light of them.

\section{ON THE RUN AS LITERATURE ...}

Ethnography is both poetry and practice and it matters greatly how it is presented. It relies in no small part on aesthetic qualities to persuade - after all, we cannot play the numbers game in the way our quantitative and statistical colleagues can - and it is no great surprise that ethnographers will typically spend a great deal of time polishing their craft. Perhaps this is why ethnography has been labeled the most humanistic of the sciences and the most scientific of the humanities ${ }^{2}$, a narrative or storytelling enterprise with the NSF stamp of approval. And On the Run can easily be slotted into either camp. We look to the literary properties of the work first.

By literary, we follow Ezra Pound's notion that literature is "news that stays news". Ethnography is first and foremost about bringing back the news - what particular people, in particular places, at particular times are doing (and, to distinguish it from journalism, notably immersion journalism, why). Despite the many years it took Alice to

\footnotetext{
2 This familiar characterization of ethnography has been attributed to the pioneering American anthropologist Alfred L. Kroeber (1876-1960). We have been unable to track down the date and location of the putative quote.
} 
complete the work, the timing of its release - 2014 - turned out to be propitious. The country's stunning rates of incarceration, especially for Black men, had become a matter of widespread concern (Alexander, 2012); deadly police shootings of unarmed Black men, captured by video, were on the nightly news giving birth to the social movement Black Lives Matter (and its backlash); and the prominence of debates surrounding the worth of "law and order," "lock-em-up," "get tough" urban policing - complete with a beefed up police presence in targeted "high crime" neighborhoods. All of which illustrate the murky but charged context into which Alice's work was read.

On the humanistic side, On the Run is a story, several stories really, of persuasive power and told largely in the first person for honesty's sake. From the innumerable details found in the book that flow from her years of living in the field, there can be no doubt that Alice was present and deeply entangled in many of the scenes she describes. The tales come rapid fire. The book is almost impossible to put down once begun. It is extremely readable, spare with jargon and disconcerting theoretical disquisitions. It makes for great reading in part because it is concerned with particularities, rendering the specifics of the lives observed up close in vivid, tense and evocative prose. In a sense, it reads less as an academic study than as a memoir, a personal account of a life on the run.

The book introduces a large cast of engrossing characters, some of whom are rather fully realized and we come to know well, even if some personal details are withheld for reasons of decency and anonymity. Alice thankfully makes little effort at reckoning with their inner-life but certainly makes us highly cognizant of the situational struggles they face day-in and day-out, legally, in the neighborhood and beyond, with family members and friends, and of course with the omnipresent "authorities," namely the police. 
The subtitle featuring the term "fugitive" is a wise and disquieting choice so used are we to thinking of the fugitive as a hardened criminal on the FBI's Most Wanted list or romanticized as Dr. Richard Kimbel falsely convicted of murdering his wife and on the run like Jean Valjean in Les Miserables. The fugitives here are low level drug dealers, living under constant threat of arrest and cycling in and out of prison. They are vulnerable young men - some as young as 11 years of age - catching cases and bench and body warrants for a variety of petty to serious violations, with the petty far outnumbering the serious: curfew violations, failure to pay child support, failure to appear, parole violations such a drinking, unpaid parking tickets or missing an appointment with a probation officer. In short, our conventional understanding of the putative "fugitive" is inverted as the number of fugitives in our imagination is enlarged exponentially. This is part Kafkaesque and part Catch 22.

As a tale, On the Run rests on the logic of discovery, not verification (although the two are intertwined in the narratives). This is a logic that is driven by surprise and curiosity rather than conjecture. Ethnography relies on fine detail to gain insight into social processes and contextualize behavior, rather than seek to generalize from what is, after all, a sample of one. Astonishment is what is delivered but in a meticulous, point by point, example after example fashion. A matter driven home when one of us was typing up some notes on the book and writing down the title of Chapter Three as "When the Police Knock on Your Door" only to find out later that the correct title reads "When the Police Knock Your Door In". These little to large shocks to our system run throughout the text. The words, phrasing, and ordering are precise, evocative, and meant to and do 
startle us - serving as something of a wake-up call to our sense of justice, fairness, equality (or lack thereof).

As a piece of ethnographic literature, shadows of this work can be found a hundred-plus years ago in W.E.B. Dubois, in the first, second and third generations of writers shaped by the Chicago School traditions of urban sociology - think of Everett Hughes, George Herbert Mead or Herbert Blumer - and in the present era of vibrant, morally engaged, field based work of a bevy of contemporary writers, journalists, anthropologists and sociologists. ${ }^{3}$ Indeed, there is a collective voice at work here beneath Alice's unique, careful and strong individual voice. Acknowled ged graciously throughout the work are many help-and-advice colleagues, a virtual Who's Who in contemporary sociology - to name just a few, Howard Becker, Charles Bosk, Elijah Anderson, Mitch Duneier, Herb Gans, Jack Katz, Diane Vaughan, Paul DiMaggio, Pattie Adler, and Bob Emerson. We often think that writing is something we do alone since we so often suppress if not ignore - in print at least - all the collective influences that surround us, those who read our drafts, encourage our efforts, chat us up, offer ideas, pick us up when we're down, and provide aid and comfort as we struggle to get it just right (which of course we never quite do) - family, friends, colleagues, students and those we know in and from the field. Here the collective voice sings between the lines in the book and, we suspect, were hugely reassuring and helpful to Alice. We don't ever do ethnography solo.

\footnotetext{
3 For illustrative purposes, consider the work, in anthropology, of Bourgois (2003) and Fassin (2013), in sociology, of Desmond (2016) and Duck (2015), and, in journalism, of Kotlowitz (1992) and Ehrenreich (2011).
} 
Of particular note on the literary side is Alice's 50-page appendix, unpretentiously titled simply, "A Methodological Note." This is a tour de force, a contemporary equivalent of Bill Whyte's belatedly written methodological appendix called "On the Evolution of 'Street Corner Society'." Here we learn that Alice or, as she was know in the $6^{\text {th }}$ street neighborhood, "A" or "Nil," the adopted sister, cousin and chronicler in the field, is less an observer than a participant and witness in the traditional and wonderfully old-fashioned ethnographic way. The field material passes through her not as "data" but as experience as transmitted eventually through composition and rhetoric. One has to "be there" and "there" is not "here." The ethnographer's fabled reflexivity and selfinterrogation is apparent in this appendix and it distinctly anything but naval gazing bear in mind Alice's striking remarks on the consequences of fieldwork on the ethnographer.

It also seems true that when the narrative virtues and pleasures of ethnography are great enough - meticulous detail, surprise, irony, drama - no one asks for conceptual niceties and analytic frames, aims, and implications are overlooked by readers (although they are surely there if only implicit). On the Run has this virtue. Twists and turns are everywhere - Alice's own turn at dipping and dodging. The larger dark, repressive, more or less institutional picture is certainly spelled out but not dwelt on and her theorizing is blessedly spare (but there). Sorting out the generalizations and implications of the work is left largely to the reader, even if in most of our own academic journals this is no longer allowed. It is fairly typical nowadays for fieldwork to be sliced and diced and relegated to tables in the interest of formulaic abstraction and conceptual summary. 
Inoculated from the editorial pressures of the journals to abstract and theorize, On the Run gives the reader the freedom to make or at least to justify their own generalizations in relation to the rich, highly suggestive, indeed graphic body of ethnographic specifics. Theory and policy wonks may not like this much but it certainly marks the work as literary. Nor would providing such a pro forma and expected social science-y conclusion have added much to the tale. The repressive state, expansion of surveillance technologies (selectively targeted) and the mass incarceration of people of a certain color and class are hardly secrets nor discoveries awaiting to be made by the Big Thinkers, sociologists or otherwise. Nor do we seem to know much about what to do as reform after reform (enlightened or not) falls flat and often creates more social problems in its wake. One is reminded of Brendan Behan's remark that he had "never seen a situation so dismal that the police couldn't make it worse."

Still, however, the view of the ghetto as populated by ignorant, criminallyminded, shiftless, lazy Black folk - as "deserving victims" - persists in the popular imagination and, like a vampire, refuses to die despite the widely reported facts on the matter, hundreds, neigh thousands of expert opinions, countless surveys, and numerous fine ethnographies. It won't go away and maybe we should be waving garlands of garlic instead of publishing books. But, alas, we must remind ourselves that more people in America believe Barack Obama is a Muslim than believe in Darwin's theory of evolution. In short, we don't need a wringing-of-hands chapter on "What Are We To Do Now." In so many ways, it is obvious from the accounts given in On the Run - we must stop this madness. 


\section{ON THE RUN AS SCIENCE ...}

On the scientific side, there is much to admire for ethnography done well is more a logic, a stance, than a method or particular study. It names an epistemology, a way of knowing and the kind of knowledge that results. It is anything but a recipe. It is improvisational, not procedural, and is path-dependent, since we learn of the subjectivity and intentionality of those we encounter in the field well after our work has begun, and the longer we are at it the more we learn about what we need to learn next. Knowledge accumulates in large part because surprise - in some sense the Holy Grail of ethnography - is inevitable and taken seriously. We spend some time in the field, meander about the scene, hang out, and talk to a few people quite different from ourselves who hold ideas that in various ways differ - often spectacularly - from our own. We learn what we can and then alter the questions we ask and the way we ask them and spend more time in the field talking to more people. As so it goes - on and on and on. Where it stops no one knows. Those who revere standardization develop a prickly rash whenever ethnographers hold forth about their craft.

And this is precisely what Alice did. For six hectic years. She was always counting something - 14 witnessed police beatings in her first 18 months, going only five days in her first two years without seeing an arrest made in the neighborhood, watching 41 cases of those who ran from the police after a stop in which 24 got away and in only 7 instances did the police catch the name of the runner. There were 71 occasions in Alice's presence where a woman was told a loved one just "caught a case" and on 58 of these occasions the woman promised to "ride" for the loved-one. Not just counts either, but finely grained "Goffmanesque" categories: Seven techniques the police use to persuade 
women to snitch on their lovers, sons and friends from "threats to arrest them" to "false promises to shield their identities." Five ways of avoiding the law when on the run. Four ways legal troubles can be converted into potential resources. Chapter Two, "The Art of Running" stands out as a favorite of ours on the social science side of the ethnographic equation. It is devastatingly spot on in digging out and dealing with the conditions in which a relatively unique event (running from the police) happens - or, better, lays out sharply the particular concatenation of events that lead to its occurrence.

There is comparative work as well as Alice looks to understand those who aren't on the run. They live in the same neighborhood under virtually the same conditions of grinding poverty and uninviting job prospects but manage to avoid the fugitive life (and not by luck alone although that is a part of it as well). Historically, Alice provides a grounded look at the rise of intensive ghetto policing drawing on other scholars' work and past ethnographic efforts at understanding urban poverty. Nor is she myopic or a knee-jerk critical theorist setting the scene as the work of a conscious conspiracy to keep young Black men in chains or the work of Foucauldian puppets caught up in a neo-liberal ideology. There is a good deal of agency on the part of all players in this portrait of, what she pointedly calls, the "last repressive regime of the age."

Importantly, she draws on the fine work of other ethnographers, elaborating and filling in gaps in our understanding of the dynamics of neighborhoods similar - but hardly identical - to the neighborhood the $6^{\text {th }}$ Street men call home. Tellingly, she adds to the useful "street" versus "decent" distinction held by many Black urban dwellers - and put forth eloquently by Elijah Anderson (1999; 2003) - by providing a cross-cutting "clean" versus "dirty" contrast. Much of what has been missed in the work of her 
predecessors is the fugitive subculture (in part because it has grown so rapidly in recent years). Alice's gaze is predominately on the "dirty" and "street," categories often put forth and certainly implied by other scholars but obliquely, at a distance, and often only by organizing and passing on to readers the tales told by residents who, like most ethnographers, place considerable analytic and representational effort in putting forth the views of the "clean" and "decent" majority in the studied neighborhoods to counter destructive and flatly wrong public stereotyping.

In many ways, Alice does exactly what one expects of a serious ethnographic effort: she organizes her material in patterns, not variables, and relentlessly chases down variance. Both these attributes give our hypothesis tracking, statistically minded and theory obsessed colleagues the hives. They, too often, overlook the discrepancy between what one expects and what happens, whereas Alice misses few opportunities here. Recognizing such gaps are essential to grasp the moment and explore the inconsistency between what is assumed and what is discovered. Probing the incongruities between previous understanding and fresh experience is precisely how ethnography penetrates the so-called taken-for-granted. In this sense, as Alice so clearly admits, there really is no end to an ethnographic project. Surprise is always lurking just around the bend. Empirical or theoretical saturation is a rather empty idea. Alice left the field when she ran out of money, had to finish her dissertation and needed a damn job. 


\section{ON THE RUN AS CAUSE CÉLÈBRE ${ }^{4}$}

While the reader response to On the Run has been on the whole favorable, indeed, for the most part, laudatory, several reviewers have pointed to what they take as possible inaccuracies in her account as well as what to them are questionable moral choices made by Alice in the field. Accusations run from the mild to the serious. Some of this is to be expected when scholars receive as widespread public attention about themselves and their work. Often such coverage is incomplete and full of misperceptions. But it is perhaps the price paid for writing and attracting a broad (read trade) audience.

The resulting kerfuffle surrounding On the Run began rudely and unceremoniously in May 2015, about a year after the book's publication, when an anonymous 60-page, single-spaced critique of the book arrived on the virtual doorsteps of several hundred sociologists. It accused Alice of numerous failures of omission and commission including, for example, lying about her presence in certain key scenes laid out in the book, allowing major discrepancies and inconsistences to sully her account, and inflating for dramatic effect the circumstances surrounding her interrogation(s) by the police. By and large, these accusations were either of a trivial sort, easily explained, or groundless. But the document got the attention of Alice's department and university and,

\footnotetext{
${ }^{4}$ In this section, we draw rather selectively on what we regard as the more incisive and serious critical responses to On the Run appearing in a variety of publications as of August, 2016. As indicated, this is a large literature and many have weighed in on the pros and cons of the work. For a taste of the celebratory response, see, Gladwell (2014) and Jencks (2014) and, for the damning, see Lubet (2015a,b) and Campos (2015). For a thoughtful and reasonably balanced journalistic view of the book, the author, and the controversy, see Lewis-Kraus (2016).
} 
after a presumably careful review, the University of Wisconsin, Madison issued a statement saying the accusations directed at Goffman were "without merit."

Some readers have argued that in the course of her work Alice became too close to her informants and, in doing so, had forsaken her duty as a researcher to be rigorous, objective and skeptical (e.g., Neyfakh, 2015). So, for example, when told by her informants that many were reluctant to visit friends or family in local hospitals for fear that they would be checked against outstanding arrest warrants, critics argued she should have questioned this by looking into police practices rather than taking what she'd been told at face value. When Steven Lubet (2015a), a legal scholar and one of Alice's fiercest critics, asked a source with the Philadelphia Police Department whether this was indeed a standard practice during her fieldwork stay, he was told: "No way. There was never any such policy or standard practice." Lubet then dismissed the book as "a cautionary tale of what can happen when researchers confuse their own voices with their subjects, and arrange the facts to support a broader, even if admirable, agenda."

Alice's rebut of these (and other) criticisms is fairly straightforward and simple. She argues with considerable justification that just because the authorities say they don't engage in such practices doesn't mean it is so. As Van Maanen (1978) has suggested in light of his fieldwork with the American police, observing the law often means not observing it. For almost 50 years, ethnographies of police organizations have demonstrated how frequently officers overstep their legal limits (e.g., Rubenstein, 1973; Manning, 2003). More pointedly, to rely on a hierarchy of credibility that privileges those at the top to define how things "really are" is to dismiss the claims of those at the bottom who have direct experience to support their version of reality. In fact, her I-witnessing 
narrative demands we take seriously the complaints of disempowered minority communities. In Alice's words: "The point of the book is for people who are written off and delegitimized to describe their own lives and speak for themselves about the reality they face, and this is a reality that absolutely goes against the narratives of officials or middle class people" (quoted in Lewis-Kraus, 2016).

No ethnography is perfect however. Her suppositions sometimes reach a level unwarranted by the data. As far as the police are concerned, our sense is that they are portrayed a bit too generically. This is a modest flaw but nonetheless noticeable. The vast majority of cops (arguably 80\%) are on street patrol and the idea of going after someone for a failure to pay a parking ticket or even tracking down and taking in a deadbeat Dad is not their idea of admirable police work (Moscos, 2009). If a warrant pops up on a street stop, they'll act but not to boost their stat count. The cops Alice appears to be talking most about are those attached to the frightening and rising number of special units in federal, state and local agencies, especially aggressive elite units charged with arrest and body counts, informal quotas and neighborhood sweeps and crackdowns. They are sometimes in uniform, sometimes undercover and do have an increasing number of tools at their disposal (read helicopters, high powered weapons, tasers, stores of tear gas, sophisticated data banks, etc.), using them routinely and with great eagerness, breaking down doors and whisking away those they seek or stand in their way while terrifying bystanders.

There are also occasional but mildly annoying lapses in citing sources - perhaps for legal concerns or simply to protect her sources. Some cops, for example, undoubtedly do swipe money when on raids but how does Alice know this beyond claims made by 
those in the neighborhood? Given her admirable penchant for careful observation and documentation, this seems a slight breach of faith. She might also have provided a bit more nuance and detail about just who specifically on the enforcement side are involved in the cases reported beyond the search and arrest stage. Oftentimes, once an arrest has gone down, the cops involved more or less wash their hands, walk away and operationally forget about it (until court time arrives if they are called) leaving it to the ADAs and detectives to worry about building a case for trial and sentencing. Yet, all in all, these are trivial complaints and, to be fair, Alice does recognize that at least some cops do see the social problems experienced by able-bodied young men in a jobless ghetto but realize as well that they are poorly equipped to provide social solutions.

In defense of her text, Alice argues that the (relatively few) inconsistencies and errors that found their way into print were inadvertent, the direct result of the extraordinary effort she went to when anonymizing the document to meet Institutional Review Board mandates and, more importantly, to protect her friends and acquaintances in the $6^{\text {th }}$ Street neighborhood. To which her critics replied that this effort at anonymization has only been partially successful. As Lubet (2015a) points out, a straightforward Google search leads to a local newspaper report that reveals the identity of the informant. And journalists have subsequently been able to also identify other informants and interview them. While some argue she had been reckless in putting her informants at risk, it is hard for us to see how she could have done much more. As Lubet suggests, the only way to keep subjects names out of the public record is to make sure that an independent inquiry never occurs. And this is clearly beyond the control of the ethnographer. 
The challenge with ethnography is that keeping identities disguised can require a great deal more than changing names, role descriptions, and physical attributes. Where the stakes are particularly high and informant communities small, ethnographers might be compelled to even alter gender, timing, and background. The difficulties these protective measures introduce are perhaps obvious: the attributes altered can be important inputs into explaining behavior. So how then do we strike the balance between rendering "true" descriptions and safeguarding the interests of those being described?

In this regard, anthropologist Paul Stoller (2016), in a sensitive and generally supportive review of On the Run, renders a useful description of the complexities ethnographers face in and out of the field:

"[Ethnographers] must build a complex web of relations between themselves and their subjects. Those relations are never straightforward. No matter where ethnographers might be ... the emotional texture of those relationships invariably shapes the kinds of information that gets exchanged as well as the nature of the text that ethnographers eventually write. In ethnography, the personal and the professional are never separate, meaning that good ethnography is not likely to consist of bloodless prose. Put another way, doing ethnography, like living life, involves love and hate, fidelity and betrayal, and courage and fear ... Those relationships ... sometimes create ethical dilemmas that no research design, no theoretical argument or set of ethical guidelines can easily resolve." 
Stoller is insisting that there aren't any hard and fast rules here. Alice comes across as singularly aligned with those she studied and when the chips are down - as they frequently are during her lengthy time in the field - she answers the perennial question asked of ethnographers, "whose side are you on", unambiguously and without hesitation in support of the embattled young men and women of $6^{\text {th }}$ Street. And she does the best she can on their behalf as, for instance, the ritual incineration of her fieldnotes indicates (a way Alice took to protect her friend-informers from police scrutiny after her book was published).

Another critique levied against On the Run is that of "other-ing" or "exoticizing" her account. Much of the book focuses on exhaustive descriptions of the down-and-out character of the neighborhood and the criminal activities of young Black men. By so doing, Alice stands accused of perpetuating negative stereotypes. One of the more interesting voices among the critics is that of Dwayne Betts (2014), a Yale academic and poet. He grew up in a similar neighborhood to Alice's $6^{\text {th }}$ Street and spent eight years in jail for carjacking. Yet he is adamant that Alice's depiction does not represent the larger community. He writes: 'I'll say what should be obvious, but isn't: Most young Black men are not committing armed robberies and burglaries, are not engaging in armed battle from moving cars, and are not murdering acquaintances at dice games. They are not shooting into homes ... Why not give us a picture ... that is broader than the last felony they committed?" This is akin to the objections of sociologist Victor Rios (2014) who takes Alice - a highly educated white woman raised in an upper middle-class environment - to task for sensationalizing her experience of "going native" while living to tell about it - in effect, writing a Kiplingesque "Jungle Book" story. 
These are fair critiques although familiar ones to ethnographers who are often attacked for not writing the sort of narrative more pleasing to certain audiences. But Alice was not interested in cleansing her account. In this sense, On the Run is written against the normative (and, to a degree, disciplinary) grain, invoking in print the raw sights and emotions of fieldwork. By straying from textual norms, she has been, as might be expected, admonished. On the Run tells troubling stories and attempts to link these stories to larger social issues. She intends to shock - hence the depictions of filthy roach infested homes, crack addictions, violent and fractured relationships, and ceaseless petty and felonious criminal activity on $6^{\text {th }}$ Street. Readers are jolted and, as a consequence, may well pay close attention to what is put forth.

Of note however, Alice's closest informants and friends do not seem unhappy with the book. Miss Linda, a central figure in the book, told a reporter that while she hadn't finished the book, "she didn't have a shred of doubt about whether Goffman told the story of $6^{\text {th }}$ Street honestly" and one of her sons said he was proud of "our book" (Lewis-Kraus, 2016). Who is to say what the "proper" thematic structure and level of detail should be for a particular ethnography? Alice paid scant attention to presumably ordinary and standard sociological conventions, opting instead to work in hybrid fashion - as both a reporter and an academic - and writing in lucid, if lurid, detail.

It is worth pointing out however that the individuals profiled in an ethnography are not always as generous as apparently those linked to Alice. Many of us bear the scars of encounters with those who unhappy with our accounts. Caroline Brettell (1996) in When They Read What We Write, noted how offended the people of Ballybran were by the publication of Scheper-Hughes's (1979) ethnography. She quotes the village 
schoolmaster: 'It's not your science I'm questioning, but this: don't we have the right to lead unexamined lives, the right not to be analysed? Don't we have a right to hold on to an image of ourselves as different to be sure, but as innocent and unblemished all the same?"

Alice Goffman seems to have been well aware of this risk, telling the journalist Lewis-Krause (2016) that she kept bringing up the fact that she was writing a book, and that betrayal would feel like sharing a family secret, "selling out the people you care about most." Still, as ethnographers, we earn our keep by exposing the lives of others, without an obligation to reciprocate the vulnerability this implies. One might counter that our informants are grown-ups who can make up their own minds, so long as we are open about the fact that we are conducting observation-based research. Here we assume that informants understand the full implications of a warts-and-all account in which they are exposed writ large, but without any right of censorship over the material. Given the difficulty of securing and sustaining access, it is tempting to disregard their ignorance and exploit the asymmetry in experience: we know this can end badly whereas they may not.

Our silence as ethnographers is never without consequence - although sometimes such silence benefits the researched. At several places in On the Run, for instance, Alice acknowledges she has information that would be of interest to the police and plausibly contribute to the safety of some in the neighborhood. But she was also embedded in a "no-snitch" community. In theory, these episodes raise serious moral challenges for the ethnographer. In practice, as Alice repeatedly demonstrates, her loyalties were given over to those she was living with and living like, the friends she had in the $6^{\text {th }}$ street neighborhood. Quite clearly she was as vulnerable to police attention and censure as 
those around her. Her vulnerability as exposed in the book is in fact an admirable rhetorical feature of the work and perhaps creates something of an empathetic understanding and connection between reader and the writer.

Arguably, the most serious challenge to be levied against Alice is for her voluntary participation in a manhunt told dramatically as the last scene in the book. In brief, Alice offers to drive a getaway car for Mike armed with his Glock on a highly questionable - for numerous reasons - mission. Of the episode, Alice says in lines that close the book:

"Looking back I'm glad I learned what if feels like to want a man to die ... and to feel it in my bones, at an emotional level eclipsing my own reason or sense of right and wrong. But to go out looking for this man in a car with someone holding a gun? ... My desire for vengeance scared me, more than the shootings I witnessed, more even than my ongoing fears for Mike's and Tim's safety, and certainly more than any fears of my own." (p. 261)

From a literary perspective, there is an unmistakable echo of Joseph Conrad's Heart of Darkness in this passage, "exterminate the brutes." Though we may not be sure who exactly the "brutes" may be - maybe us, the smug and complacent - but having read the book we can understand her feeling. Yet, while the experience may have been instructive, Alice, under Pennsylvania law, committed a felony by voluntarily driving a would-be getaway car. Even Alice's $\mathrm{PhD}$ supervisor from Princeton, Mitchell Duneier, agreed that she had crossed a legal line by her actions (Lewis-Kraus, 2016). 
Alice could have covered herself by adding another paragraph or two of detached analysis that would have contextualized the scene as she (and others) understood it - as something of a charade, more a mourning ritual and face-saving ceremony. Everyone knew, as did she, Chuck's killer had long since fled the neighborhood. She clarified the context much later in a public response to her critics, a rejoinder that seems to have satisfied most (but not all) of her detractors (Goffman, 2015). But perhaps Alice felt that to do so in the book would have distanced herself and therefore misrepresented her deep penetration into the lives of those researched and the emotional intensity, the blood-lust, she felt at that moment. As Lewis-Kraus observed, this is a book about men whose entire lives had been criminalized and Alice Goffman, to her credit, didn't hesitate to criminalize her own.

It is the case too that ethnographers - but especially those whose research involves crime, drugs, poverty, police - do not report incidents that could potentially compromise their work and themselves. They surely occur but we never learn of them. The line Alice crossed is therefore one of being too honest, coming forward when the unstated norm is to hold back. Remember too that this incident is recounted in a methodological appendix where the ethnographer's sharing what she felt "in her bones" is exactly the sort of emotionally resonate revelation that is encouraged, typically applauded, as a display - however rare - of welcome reflexivity.

On the Run is important then for raising the sorts of questions an ethnographer is likely to confront - albeit, in less precarious and menacing circumstance - when plunging head-first into alien worlds. Whatever the eventual legacy of the work, it has sparked important conversations; and not just about the policing and constant surveillance of 
young people in one relatively poor Black neighborhood but about the inherent messiness and difficulty of trying to capture someone else's truth, or what it is like to be someone else. By and large, we feel there is far more smoke than fire when it comes to the allegations of Alice's impropriety. Certainly the book is contradictory in places, takes certain liberties of expression, and is full of moral choices some of us would not make. But, in terms of the book's purported failings and inconsistencies, we know of few works that - subject to the same sort of punitive audit On the Run has been put through - would fare as well.

Some will of course continue to regard the book as too journalistic, too descriptive, too sensational, and too wrapped up in its first-person narrative. Others will say it jettisoned rigor, dispassion, theory. It sits uneasily (although accordingly and perhaps ideally) between the literary and the scientific. Do these "flaws" - as seen from either side - diminish the contribution of On the Run? We think not but, ultimately, the real test of ethnography is whether or not it has staying power or, in the vernacular, "legs." We believe it does - although it is probably too early to tell. As such, we take it as an exemplary work meeting if not exceeding many of the characteristics of what we would call a "classic" ethnography.

\section{WHAT MAKES FOR A CLASSIC ETHNOGRAPHY?}

We have four features in mind that mark what we are calling a classic work. For starters, high-quality ethnography is relatively free from technical jargon and high-wire abstraction. While polysyllabic postmodernism is not altogether absent from contemporary ethnographic circles, it is infrequent. Indeed, in what we would label the mainstream realism of ethnography concepts are borrowed, often with telling and 
persuasive effects, from broad public discourse and, for better or worse, an anti-theory bias remains apparent. Representation by what anthropologist Richard Shweder (1991) calls the "merchants of astonishment" rather than generalizations by "human nature experts" remains the primary authorial pose in the trade where surprise, frame-breaking, exceptions to the norm shape the analytic domains of ethnography. Abduction, not induction or deduction, is the name of the game. On all these dimensions, On the Run gets high marks.

Second, because of this relative freedom from a thoroughly specialized vocabulary and a privileged conceptual apparatus, high quality ethnography continues to carry a slight to distinct literary air compared to other forms of social science writing. It remains a less congealed, passive-verb, impersonal and congested form of discourse keeping the non-specialist interested in what we do as Alice has demonstrated with striking force - consider the barrage of publicity On the Run has generated. Such work pushes ethnography into the trade and so-called - if rather fabled and hard to define public intellectual domain bringing the seemingly distant, deviant and alien worlds investigated to readers well beyond the pinched warrens of our own research guilds. Perhaps suggesting to readers that what the men and women of $6^{\text {th }}$ Street want and value for themselves, their loved ones, their children are pretty much the same as what those in Westchester County or Cambridge, Massachusetts want and value as well - namely justice, opportunity, decency, compassion, respect and a safe haven.

Third, high quality ethnography maintains an almost inescapable and die-hard focus on the "empirical." The witnessing ideal - famously celebrated by Clifford Geertz with its intense reliance on personalized seeing, hearing, experiencing - continues to 
generate among ethnographers something of a hostility to generalizations and abstractions (read, sacred theory) not connected to immersion in situated detail. Other forms of data are acceptable in ethnography of course and responsible scholarship requires a sort of interdisciplinary contextualization of places, times and settings in which we work - multiple and rather de-territorialized these days. While spare, Alice does this splendidly but with restraint, treating these other forms of evidence and argument as acceptable but only as a concession to practicality. Who would want to count the number of young Black men in prison ethnographically? In the end, it is her ability to convince us as readers that what we are reading is an authentic tale written by someone deeply familiar and knowledgeable about how things go down in some specific place, at some specific time, among some specific people is what counts. Everything else that ethnography tries to do - to edify, challenge, annoy, surprise, amuse, critique and, yes, theorize - rests on this. And in this regard, there can be no doubt as to her presence.

Finally, even in high-quality work (or maybe most noticeably in high-quality work) there is not much of a technique attached to the ethnography beyond "being there." Ethnography in this regard cannot and will not be made safe for science, leaving it immune to a standard methodology that would effectively neuter or perhaps destroy the Columbian or adventuresome spirit that Alice brings to this work. This feature of the work might lead some readers of On the Run to wonder whether or not Alice has produced the one "real" or "authentic" ethnography of the neighborhood. Would a young French ethnographer like Michel Anteby or a British critical theorist like Paul Willis see $6^{\text {th }}$ Street as Alice did? We doubt it (although surely there would be overlaps). If more than one ethnography is possible, there can't be a single "real" ethnography. They will be 
different because of the different contributions the ethnographer and community press into the writing, the different ways a study moves, the different choices made along the way, the different events taking place in the world studied in different times, and so on (and on). Alice says as much in the book alluding to both her arbitrary exit and her telling confession that we quote: "I never got to the point of saturation or when I was not learning new things."

To close, On the Run presents "news that will stay news" for some time to come. Deserved so. And, as hinted at in the book, Alice's work is far from complete in the sense that exit - or, gasp, the even the demise of the fieldworker - doesn't conclude the enterprise. Given the infinite complexities of social life, the quest for the perfect representation of reality is an illusion. Given the inevitability of restudies, another generation of ethnographers will take up arms to show their forbearers a new wrinkle or two. Unmarked or underplayed features of the worlds represented will be brought to light. Errors will be revealed. Changes will have taken place. Ethnographic projects have beginnings of course but no clear endings. But let us hope that Alice's work stands years from now as a fine and sweeping period piece, documenting a depressingly dark era in American history. There are a few weak signals arising - incarceration rates are declining slightly, some courts are refusing to enforce three-strike mandates, stop-and-frisk policies are under review, and the like - suggesting we may be taking a few steps on that yellow brick road to a more just and equitable state. We have our doubts of course (cue Eric 
Garner, Trayvon Martin, Tamer Rice and "hands up, don't shoot" Michael Brown). ${ }^{5}$ But maybe, just maybe, Alice's dogged fieldwork and vivid prose will push us further down that road.

5 These are but a few examples - highly visible ones - of the many Black lives taken in recent years under questionable circumstances. Eric Garner and Michael Brown were unarmed Black men killed by white police officers in the US. Garner died from a chokehold applied by New York city police officers and Brown was shot by a Ferguson, Missouri policeman. Tamir Rice was an unarmed 12 -year old boy fatally shot by a white officer in Cleveland. Trayvon Martin was an unarmed Black youth shot and killed by George Zimmerman, a white neighborhood watch volunteer, in Sanford, Florida. Widespread protest followed in their wake. No charges against the police officers were filed and Zimmerman was found not guilty of second-degree murder. 


\section{References}

Alexander, M., 2012. The New Jim Crow: Mass incarceration in the Age of

Colorblindness. NY: The New Press.

Anderson, E., 1999. Code of the Street: Decency, Violence and the Moral Life of the Inner City. New York: Norton.

Anderson, E., 2003. A Place on the Corner. Chicago: University of Chicago Press.

Anteby, M., 2008. Moral Gray Zones: Side Productions, Identity, and Regulation in an Aeronautic Plant. Princeton University Press.

Anteby, M., 2013. Manufacturing Morals: The Values of Silence in Business School Education. Chicago: University of Chicago Press.

Barley, S. R. and Kunda, G., 2006. Gurus, hired guns, and warm bodies: Itinerant experts in a knowledge economy. Princeton: Princeton University Press.

Betts, D., 2014. The Stoop Isn't the Jungle. Slate, 10 June 2014 (available online at: http://www.slate.com/articles/news_and_politics/jurisprudence/2014/07/alice _goffman_s_on_the_run_she_is_wrong_about_black_urban_life.html) 
Bourgois, P., 2003. In Search of Respect: Selling Crack in El Barrio. NY: Cambridge University Press.

Brettell, C., 1996. When They Read What We Write: The Politics of Ethnography. NY: Praeger.

Desmond, M., 2016. Evicted: Poverty and Profit in an American City. NY: Crown.

Duck, W., 2015. No Way Out: Precarious Living in the Shadow of Poverty. Chicago: University of Chicago Press.

Ehrenreich, B., 2011. Nickeled and Dimed: On (Not) Getting By in America. NY: Picador.

Fassin, D., 2013. Enforcing Order: An Ethnography of Urban Police. Malden, Ma.: Polity Press.

Gladwell, M., 2014. The crooked ladder: the criminal's guide to upward mobility. The New Yorker, 11 and 18 August 2014 (available online at: http//www.newyorker. com/ magazine/2014/08/11/crooked-ladder)

Goffman, A., 2014. On the Run: Fugitive Life in an American City. NY: Picador. 
Goffman, A., 2015. A Reply to Professor Lubet. (available at http://www.ssc.wisc. edu/soc/faculty/docs/goffman/A\%20Reply\%20to\%20Professor\%20Lubet.pdf)

Ho, K., 2009. Liquidated: An Ethnography of Wall Street. Durham, NC: Duke University Press.

Jencks, C., 2014. On America's Front Lines. New York review of Books. 9 October 2014.

Kellogg, K. C., 2011. Challenging Operations: Medical Reform and Resistance in Surgery. Chicago: University of Chicago Press.

Kotlowitz, A., 2013. Deep Cover: Alice Goffman's 'On the Run.' New York Times Sunday Book Review. 26 June 2014.

Kotlowitz, A., 1992. There Are No Children Here: The Story of Two Boys Growing Up in the Other America. New York: Doubleday.

Lane, C., 2011. A Company of One: Insecurity, Independence and the New World of White Collar Unemployment. Ithaca, NY: ILR Press.

Lewis-Kraus, G. 2016. The Trials of Alice Goffman, The New York Times, 12 Jan 2016 (available online at: http://www.nytimes.com/2016/01/17/magazine/the-trials-of-alicegoffman.html?_r=0) 
Lubet, S. 2015a. Ethics on the Run. The New Rambler. (available online at: http://new ramblerreview.com/book-reviews/law/ethics-on-the-run)

Lubet, S. 2015b. Alice Goffman's Denial of Murder Raises Even More Questions. The New Republic, 3 June 2015 (available online at: https://newrepublic.com/article/ 121958/sociologist-alice-goffman-denies- murder-conspiracy-run)

Manning, P. K., 2003. Policing Contingencies. Chicago: University of Chicago Press.

Moscos, P. 2009. Cop in the Hood: My Year Policing Baltimore's Eastern District. Princeton: Princeton University Press.

Nadeem, S., 2011, Dead Ringers: How Outsourcing in Changing the Way Indians Understand Themselves. Princeton University of Princeton Press.

Neyfakh, L., 2015. The Ethics of Ethnography. Slate. 18 June 2015 (available online at http://www.slate.com/article/news_and_politics/crime/2015/06.alice_goffman)

Rios, V., 2014. Book Review. American Journal of Sociology. 1, 121, 131-2.

Rubenstein, J., 2003. City Police, NY: Ballantine. 
Scheper-Hughes, N., 1979. Saints, Scholars and Schizophrenics: Mental Illness in

Rural Ireland. Berkeley: University of California Press.

Sharone, O., 2013. Flawed System, Flawed Self: Job Searching and Unemployment

Experiences. Chicago: University of Chicago Press.

Shweder, R. A., 1991. Thinking Through Cultures: Expeditions In Cultural Psychology. Harvard University Press.

Stoller, P., 2015. Alice Goffman and the Future of Ethnography. The Huffington Post. 6 June 2015 (available online at www.huffingtonpost.com/paul-stoller/alice-goffman-andthe-future-of-ethnography-_b_7585614.html)

Turco, C. J., 2016. The Conversational Firm: Rethinking Bureaucracy in the Age of Social Media. NY: Columbia University Press.

Van Maanen, J., 1978. On Watching the Watchers. In P.K. Manning and J. Van Maanen (eds.) Policing: A View from the Streets. NY: Random House, 309-350. 
John Van Maanen (jvm@ mit.edu) is the Erwin Schell professor of organization studies at the Sloan School of Management, Massachusetts Institute of Technology. He works with the fields of organization behavior and theory as an ethnographer of occupations and organizations. Cultural descriptions figure prominently in his studies of the work worlds of the patrol officers and detectives, of fishermen, and of Disneyland employees.

Mark de Rond (mejd3@cam.ac.uk) is professor of organizational ethnography at Judge Business School, University of Cambridge. A recurring feature in his work is the lived experience of high performing environments, specifically the processes by which people reconcile themselves to the contradictions, and moral challenges, inherent in such contexts. His most recent fieldwork involved a world-first attempt to scull the navigable length of the river Amazon, unsupported. 